\title{
REFORMASIE John Knox, die Skotse Calvinis 3
}

\section{Deurvoering van die Hervorming in Skotland.}

Knox land in Skotland op 2 Mei 1559 in die hitte van die stryd, of soos hy dit self noem, in the brunt of the battle". Maria die regentes het nou openlik haar ware kleure gewys en sy dagvaar die Protestantse predikers Harlow, Douglas en Willock om op 10 Mei in die kasteel van Stirling te verskyn (Fleming, p. 42). John Knox neem hom voor om self daar teenwoordig te wees om, soos hy skryf, deur sy lewe of deur sy dood God se Naam te verheerlik (Laing, p. 21).

Die nuus van die dapper Hervormer se aankoms in Skotland was so 'n groot verskrikking vir die Papiste dat hulle vergadering in Edinburgh vergoed verdaag het (Wodrow Misc., p. 56). Vanaf Dundee vergesel Knox voorts die gedagvaarde predikers na Stirling, maar om nie die opmars in 'n opstand om te sit nie, word die Protestantse edelman Erlisine vooruit gestuur om met Maria te onderhandel. In 'n brief aan haar word sy deur die ,professouris of Christis Evangell in the realme of Scotland" weereens opgeroep tot bewaring van God se Woord en tot verwerping van alle afgodery (Fleming, p. 44). Kenmerkend is die onderskeiding wat in hierdie brief tussen Kerk en Staat gemaak word. Duidelik sien ons Calvyn se invloed.

Die regentes het beloof om die dagvaring van die predikers te herroep, maar spoedig het dit geblyk 'n klomp mooi woorde te wees. Die predikers word voëlvry verklaar, net soos Knox 'n paar dae vroeër.

Die Protestante was intussen nog te Perth gemonster. Op 11 Mei bestyg Knox die preekstoel van die St. Johnskerk en in 'n vurige preek ontmasker hy die afgodediens van die Roomse Kerk en lê veral klem op die mis. Na die diens, toe die meeste alreeds huiswaarts gekeer het, dwing 'n priester homself na vore en begin die mis te bedien. 'n Jong seun maak 'n opmerking, die priester gee hom 'n oorveeg en op sy beurt slinger die seun 'n klip wat een van die beelde in die kerk tref. Toe was die gort gaar. Die beeldestorm van Perth het begin en die "rascal multitude" soos Knox hulle noem, ruk hande uit. Soos 'n vinnige veldbrand is al die kerke en kloosters in die omgewing bestorm.

Die koningin-regentes het nou 'n uitstekende kans gehad en sy het nie op haar laat wag nie. Met haar Franse en Skotse troepe is die opmars teen die Protestante begin. Aan beide kante word daar na die swaard gegryp en die Hervorming kry 'n radikale karakter. Eintlik het dit meer na 'n rewolusie as na 'n Hervorming gelyk.

Knox het hom egter nie van stryk laat bring nie. Hy was nog elke oomblik oortuig dat die Protestante se saak reg is en sy prediking weerklink nou heftiger as ooit in plekke soos Crail en Anstruther en hy is selfs op pad na St. Andrews, die plek waarvan hy op die galeiskip gesê het: „Where God first in public opened my mouth to his glory" (Croft Dickinson, i, p. 109). 
St. Andrews was die sterk vesting van die aartsbiskop Hamilton. Maar ten spyte van sy honderd speerdraers om Knox buite te hou, verskyn die Hervormer op 11 Junie en die volgende drie dae op die kansel. Die inwoners is so deur sy prediking besiel, dat St. Andrews van al sy voorwerpe van afgodery en bygeloof gereinig is. Op die plek waar Walter Mill, die laaste martelaar, verbrand is, het hierdie onrein maaksels in rook opgegaan (Appreciations by United Original Seceders, p. 42).

Die konflik tussen die owerheid en die Protestante, bekend as die „Congregation", het al heftiger geword. Maria met haar Franse troepe het geleidelik die oorhand begin kry. Die Protestante het by Engeland, waar Elizabeth nou regeer het, hulp gesoek (Lindsay, ii, p. 294). Die toestand het uiters kritiek geword vir die saak van die Hervorming. Maar hoe donkerder die stryd, hoe sterker het Knox se geloof na vore gekom. Onverpoosd preek hy. So skryf hy op die 23ste Junie: ,...... for now, forty days and more, had my God used my tongue in my native country, to the manifestation of His glory" (Hay Fleming, p. 53). In die hitte van die stryd het hy feitlik nie meer tyd om sy korrespondensie te doen nie. „In twenty-four hours, I have not four free to natural rest . . . . I write with sleeping eyes."

Intussen het die "Congregation" Edinburgh binnegetrek. Op 13 Julie word Knox as die predikant van Edinburgh verkies en die organisasie van die Kerk sou begin. Maar deur die sterk magte van die regentes moes die
Protestante weer spoedig die wyk neem.

Engelse hulp het egter teen die middel van 1560 opgedaag en dit het 'n gunstige wending gegee. Kort daarna sterf Maria en haar plek sou later in die jaar deur haar dogter, die reeds gekroonde Maria wat nog altyd in Frankryk was, ingeneem word.

Intussen vergader die Skotse Parlement in Augustus 1560. Knox preek nou elke dag in Edinburgh en verklaar die profesie van Haggai - die heropbou van die tempel. St. Giles-katedraal word die brandpunt waar die Woord gehoor word, en Knox staan aan die spits van die ongeëwenaarde beweging om die mag van Rome uit Skotland te ban.

Tydens hierdie Parlementsitting word 'n petisie ingehandig deur Knox en die Protestante waarin gevra word ,freedom and liberty of conscience with a godly reformation of abuses." Hulle pleit voorts dat die suiwere bediening van God se Woord en Sakramente volgens die Skrif en die handhawing van die kerklike tug deur wetgewing van die Parlement weer moet ingestel word (Croft Dickinson, i, p. 336).

Die Confession of Faith wat deur John Knox en 'n paar helpers binne vier dae daarna opgestel is, word deur die Parlement anvaar en so word die Rooms-Katolieke hiërargie vergoed omvergewerp en die Gereformeerde godsdiens deur die Staat aangeneem. Skotland het finaal 'n Protestantse land geword met 'n Calvinistiese belydenis, ,that doctrine .... for the which we have sustained infamy and danger" (Croft Dickinson, ii, p. 257). 
Maar die Kerk moes van sy fondamente af gebou en georganiseer word. Daarvoor was nodig die Book of Discipline (Ibid, p. 280). Onder andere word hierin maatreëls vir die Christelike onderwys neergelê, die handhawing van die kerklike tug en die goeie orde van die samelewing uiteengesit. Om dit alles te verkry sou die nuut gereformeerde Kerk veel stryd kos. En veral vir Knox sou die volgende dekade wat ook sy laaste lewensjare sou wees, 'n tydperk van intense worsteling beteken. Hierdie stryd het weer eens in ' $n$ openlike konflik tussen die Protestante en Rome ontbrand toe die jong koningin van Skotland, Maria, vanuit Frankryk teen die einde van 1560 gekom het.

Maria se koms het baie moeilikhede veroorsaak. Sy is natuurlik al reeds vroeg in haar jeug met 'n doel na Frankryk gestuur. Daar sou sy aan die Franse hof opgevoed word in die godsdiens van Rome. Toe sy nog maar 'n klein dogtertjie was het 'n Franse skip haar kom haal ,that in her youth she should drink of that liquor that should remain with her all her lifetime, for a plaque of this realm ..." soos Knox dit uitgedruk het (Croft Dickinson, i, p. 103).

Hierdie jong koningin sou van die begin af as ' $n$ instrument van die Pous haar rol begin speel. Dadelik na haar aankoms laat sy die mis in die paleis vier. Maar John Knox was nie 'n man om uit te tart nie, selfs nie eers deur 'n koningin nie. Die vurige prediker, die "Thundering Scot", soos sommige hom noem, laat dit in duidelike taal van die preekstoel van St. Giles weergalm: "Dat die Roomse mis in Skotland gevier word, vrees ek meer as tienduisend gewapende vyande wat hier land om die godsdiens te onderdruk!"

Nou het die eintlike stryd verder sentreer om die konflik tussen die jong sjarmante Roomsgesinde koningin van Holyrood-paleis en die Calvinistiese prediker van Edinburgh.

'n Paar dae na Maria se aankoms, daag sy John Knox om voor haar te verskyn. Onder andere beskuldig sy hom van opstand en rebellie, dat hy 'n boek teen haar geskryf het en dat hy in Engeland oproer veroorsaak het. Maar wat van Paulus gegeld het, was in 'n sekere sin ook van toepassing op John Knox: ,.... hy is vir My 'n uitverkore werktuig om My Naam te dra voor nasies en konings" (Hand. 9:15). So verdedig die Skotse Hervormer dan sy standpunt in die paleis: „As die prediking van die goddelike waarheid en die oproep van die volk tot 'n suiwer Skriftuurlike godsdiens opstand is, dan pleit ek skuldig."

'n Reeks konflikte tussen Maria en Knox het gevolg en elke keer was die Hervormer se verdedigingsredes 'n skitterende triomf. Politieke intriges met Rooms-Katolieke skemas en sameswerings het sake vir die gevestigde Protestantse Kerk uiters moeilik gemaak. In besonder het Knox vervolging verduur. Terwyl hy een aand besig was met studie, is 'n koeël selfs deur sy venster van buite af gevuur.

Maar ten spyte van al die teenstand is die Hervorming sodanig deurgevoer in die Kerk dat Knox self kon verklaar:

,For, as touching the doctrine taught by our ministers, and as touching the administration of Sacraments used in 
our Churches, we are bold to affirm that there is no realm this day upon the face of the earth, that hath them in greater purity" (Croft Dickinson, ii, p.3).

Die aandskemering van Knox se lewe sou egter aanbreek. Die liggaamskragte wat alreeds so vroeg op die wrede galeiskip geknak is en van toe af nog deurgaans 'n aanhoudende spanning moes verduur, het by die nadering van die ouderdom eensklaps vinnig agteruitgegaan. In Oktober $1570 \mathrm{kry}$ hy 'n aanval van beroerte. Dit was duidelik dat die einde nie meer baie jare ver is nie. Maar as Knox se teenstanders hulle oor sy liggaamlike terugslag sou verheug, sou hulle spoedig teleurgesteld wees. Hoewel die liggaam feitlik uitgebrand was, het sy gees nog 'n geweldige vuur vertoon. Selfs uit sy prediking het daar tot op die laaste 'n dinamiese krag gestraal. Luister wat sê iemand wat hom in sy laaste lewensjaar hoor preek het:

„Ek het probeer om sy preke uit Daniël neer te skryf. In die verklaring van sy teks wat omtrent 'n halfuur geduur het, was sy voordrag baie kalm. Maar sodra hy sy toepassing begin het het hy my behoorlik so laat bewe dat ek nie meer die pen kon vashou nie" (M'Crie, p. 264).

Dit was ook in Knox se laaste dae dat die verskriklike bloedbad van St. Barthelomeusnag bekend geword het. Dit het die groot Hervormer nog dieper gewond as sy liggaamlike krankheid. Maar hy was nog sterk genoeg om in 'n vurige preek voor die Franse Ambassadeur Le Croc hierdie verskriklike skanddaad van Frankryk te ontmasker (M'Crie, p. 269).
Op Sondag, 9 November 1572, het Knox sy laaste preek waargeneem toe hy Lawson as sy opvolger bevestig het en op 24 November is hy na 'n moeisame lyding oorlede. Gedurende sy siekbed moes sy vrou telkens gedeeltes uit die Skrif en ook van Calvyn se preke uit Efesiërs voorlees. „Go read where I cast my first anchor" het hy gesê, en sy het na die sewentiende hoofstuk van die Evangelie van Johannes geblaai.

Kritiese waardering van Knox

as Hervormer.

Die bekende skrywer Thomas Carlyle het gesê: „.... (what) Knox did for his nation, I say, we may really call a resurrection as from death. .... He is the one Scotchman to whom, of all others, his country and the world owe a debt" (Hero Worship, p. 134).

Voor alles was John Knox 'n man van die daad. Daarby was hy radikaal en uitgesproke ....'n karaktereienskap wat ons soms by 'n waardering van sy werk verleë laat staan. Maar dit is Knox. Hy was die regte man op die regte plek. Hy was SKOTLAND se Hervormer. Juis Skotland waar die toestand van die Kerk allerellendigs was (vgl. eerste artikel) en waar chaos naderhand totale oorhand gehad het, juis daar word John Knox geroep. Die nood van die land het feitlik geëis dat die Hervormer niemand anders as juis Knox kon wees nie ... . die praktiese, radikale, nugtere, "narrow-minded" Skot, die man wat inderdaad kon sê: Veni, vidi, vici. Vir hom was alles konkreet en reël. Waar hy gepreek het, het altyd iets gebeur, want dit was die duidelike aktuele Woord, die ,plain Word of God" soos hy dit noem. Hy was 
nie geleerd soos die uitnemende teoloog van Genève nie en hy het ook nie die talente van 'n Luther besit nie, maar Knox was by uitstek die man wat gedoen het wat sy hand gevind het om te doen, en dit op sy eie kenmerkende manier.

Knox se arbeid as Hervormer word by uitstek gekenmerk deur die sterk fomele aard daarvan. Deut. 4:2 word feitlik die rigsnoer van sy reformatoriese beleid (,Julle mag by die Woord wat Ek julle beveel, niks byvoeg nie, en julle mag daarvan niks weglaat nie"). In een van sy verdedigingsredes sê Knox dan ook:

„All worshipping, honouring or service invented by the brain of man in the religion of God, without his own express commandment, is idolatry" (Laing, ii, p. 34). Laat ons 'n enkele voorbeeld noem van hoe hy hierdie beginsel toepas: As hy die Roomse mis as afgodery bestry, doen hy dit nie met die gewone materiële argument van die ander Hervormers, nl. kreatuurvergoding, nie, maar met die formele argumente dat dit nie in die Skrif beveel is nie (Vgl. Laing, iii, pp. 33-70). Sonder om in besonderhede te gaan, lê dit voor die hand dat hierdie rigting soms 'n baie gevaarlike pad kan wees.

Dit is dan juis ook in die sterk belklemtoning van die formele waarin John Knox van sy leermeester Calvyn verskil. Calvyn se eerste geskrif is die „Institutio religionis christianae”. Dit gaan in die eerste plek vir Calvyn om die „doctrina". By Knox is dit egter anders. Hy omhels die volle waarheid teenoor die valsheid van Rome, hy handhaaf die "doctrina", maar die beklemtoning kry 'n ,uiterlike" karakter. (Met „uiterlik" bedoel ons nie dat dit die inhoud verwerp nie). Knox was inderdaad 'n Puritein.

Maar ten spyte van 'n ander beklemtoning as Calvyn, was John Knox tog CALVINIS! En as Calvinis het hy sy grootste bydrae gelewer in die Hervorming van Skotland. Die leerskool van Genève en die Institusie van sy leermeester het hom in staat gestel om in die Confession of Faith en in die Book of Discipline die Calvinistiese riglyne neer te lê. In leer, diens en tug het die Skotse kerk 'n Calvinistiese Kerk geword. En hoewel daar (soos ook in ander Calvinistiese lande) in die eeue wat gevolg het, weer verval en afdwaling ingetree het, is daar vandag nog in Skotland 'n bolwerk van Calvinisme. Die stryd is uiters hard en in baie opsigte moeiliker as by ons in SuidAfrika, maar die "oorblyfsel" is daar! En al sou die kerkgebou waar John Knox met soveel vuur die suiwere Waarheid verkondig het, vandag vir hom onherkenbaar wees, is daar in Skotland nog duisendes wat sy Calvinistiese beginsels huldig. (Die kerkgebou waarna ons hier verwys is verskeie kere deur die skrywer van hierdie artikel besoek en met leedwese moet ons konstateer dat daar vandag alles behalwe 'n Calvinistiese gees in prediking en erediens geopenbaar word. Dit is die St. Giles-katedraal)

Ten suide van die St. Giles-katedraal in Edinburgh, lê daar in die straat van „Parliament Square” 'n klein vierkantige ysterplaatjie van ongeveer 6 duim by 6 duim. Daarop staan: I.K. 1572. Hierdie plaatjie dui die plek van John Knox se graf aan. Toe die lig. 
gaam van die groot Hervormer die dag daar weggelê is, het die regent Morton gesê:

„Here lies one who neither flattered nor feared any flesh." Maar uit die lewe van John Knox leer ons dat daar by hom 'n ander ,vrees" was. En hierin kan ons hom maar navolg:

"Vrees God en hou Sy gebooie; want dit geld vir alle mense" (Pred. $12: 13$ ).

V. E. D'ASSONVILLE.

$$
\text { (Slot). }
$$

\section{GERAADPLEEGDE WERKE:}

W. Croft Dickinson: John Knox's History of the Reformation in Scotland, London, 1949.
D. Hay Fleming: The Scottish Reformation, Edinburgh, 1926 (agste druk).

David Laing: The Works of John Knox (6 dele), Edinburgh, 1846-1864.

Thomas M'Crie: Life of John Knox, Edinburgh, 1855.

P. J. Kromsigt: John Knox als Kerkhervormer, Utrecht, 1895.

Thomas Carlyle: Hero-Worship, London, 1904.

T. M. Lindsay: A History of the Reformation (Deel 2), Edinburgh, 1956.

Appreciations by United Original Seceders (lesings oor Knox), Edinburgh, 1905.

The Miscellany of the Wodrow Society (Deel 1), Edinburgh, 1844. 